DOI:10.17951/h.2016.50.1.725

\begin{tabular}{lcl}
\hline \multicolumn{3}{c}{ A N N A L E S } \\
UNIVERSITATIS MARIAE CURIE-SKŁODOWSKA \\
LUBLIN - POLONIA \\
VOL., 11 \\
SECTIOH H
\end{tabular}

Uniwersytet w Białymstoku. Wydział Ekonomii i Zarządzania

\title{
RENATA BUDLEWSKA
}

r.budlewska@uwb.edu.pl

\section{Ulga na dzieci jako instrument realizacji polityki prorodzinnej $w$ Polsce*}

Child Tax Credit as an Instrument of Family Policy in Poland

\begin{abstract}
Słowa kluczowe: ulga prorodzinna; polityka prorodzinna; tax expenditures; podatek dochodowy od osób fizycznych
\end{abstract}

Keywords: child tax credit; pro-family policy; tax expenditures; personal income tax

Kod JEL: H21; H24; J13

\section{Wstęp}

Wsparcie rodziny jest w ostatnich latach jednym z kluczowych obszarów aktywności polskich władz publicznych. Intensyfikacja działań mających na celu zapewnienie dobrostanu rodziny ma uzasadnienie m.in. w pesymistycznych prognozach demograficznych przedstawianych w licznych raportach i opracowaniach instytucji rządowych i pozarządowych. Na przykład w raportach publikowanych przez Rządową Radę Ludnościową sytuację demograficzną Polski określa się jednoznacznie jako kryzys demograficzny ${ }^{1}$ ze względu na systematyczny spadek liczby ludności

\footnotetext{
* Badania zostały przeprowadzone w ramach grantu sfinansowanego przez Narodowe Centrum Nauki, przyznanego na podstawie decyzji nr DEC-2014/13/N/HS4/02870.

1 Uzasadnienie tak radykalnego określenia negatywnych tendencji demograficznych zostało przedstawione m.in. w raporcie za lata 2013-2014 [szerzej: Rządowa Rada Ludnościowa, 2014].
} 
na skutek utrzymującej się od prawie 25 lat depresji urodzeniowej [GUS, 2015]². Konsekwencją tych tendencji ma być w niedługiej perspektywie głęboki kryzys finansów publicznych i upadek systemu emerytalnego [Sobociński, 2014].

Poza tradycyjnie realizowanymi wydatkami publicznymi, środki publiczne są kierowane do rodzin w Polsce za pomocą ulg podatkowych zawartych w konstrukcji poszczególnych podatków. W 2013 r. 48\%³ tzw. tax expenditures, czyli wydatków publicznych realizowanych przez specjalnie zaprojektowane ulgi podatkowe, realizowało właśnie ten cel [Ministerstwo Finansów, 2015], z tego 5,5 mld zł dotyczyło największej ulgi w polskim systemie podatkowym bezpośrednio skierowanej do rodzin z dziećmi, tj. ulgi prorodzinnej. Od momentu wprowadzenia ulgi, tj. 2007 r., stała się ona przedmiotem ożywionej dyskusji, w której kwestionuje się, po pierwsze, skuteczność realizacji celów prorodzinnych za pomocą ulgi podatkowej ${ }^{4}$ ze względu na generalną zawodność ulg podatkowych w realizacji celów polityki społeczno-gospodarczej państwa, po drugie, zbyt ogólne sformułowanie celów postawionych przed ulgą, i - po trzecie - niedopasowanie celów stawianych przed ulgą do rzeczywistych problemów demograficznych zasygnalizowanych we wstępie.

Celem opracowania jest przede wszystkim wskazanie konsekwencji realizacji polityki prorodzinnej w Polsce za pomocą ulgi na dzieci. Obszar konsekwencji zostanie zawężony do prezentacji wybranych aspektów pozwalających na ocenę skuteczności tej ulgi, ze szczególnym uwzględnieniem oceny zmian wprowadzonych do konstrukcji ulgi w ubiegłych latach. Artykuł został przygotowany na podstawie danych źródłowych publikowanych przez Ministerstwo Finansów oraz aktualnego dorobku literaturowego w zakresie polityki podatkowej.

\section{Konstrukcja ulgi prorodzinnej w polskim podatku dochodowym od osób fizycznych}

Ulga na dzieci została wprowadzona do konstrukcji podatku dochodowego od osób fizycznych w 2007 r. Jej celem, ze względu na niekorzystne wskaźniki demograficzne kraju, miało być wsparcie rodzin z dziećmi (zwiększenie wskaźnika

2 W 2013 r. współczynnik dzietności ogólnej wyniósł 1,26, co oznacza, że na 100 kobiet w wieku rozrodczym (15-49 lat) przypadało 126 urodzonych dzieci. Od lat 90. XX w. wartość współczynnika dzietności ogólnej kształtuje się poniżej 2, podczas gdy wielkość optymalna - określana jako korzystna dla stabilnego rozwoju demograficznego - to 2,10-2,15 [szerzej: GUS, 2015].

3 Wartość tax expenditures w polskim systemie podatkowym w 2013 r. Ministerstwo Finansów [2015] oszacowało na 85,0 mld zł, tj. 5,2\% PKB, z czego 76,9 mln zł jest uszczupleniem budżetu państwa.

4 W niniejszej pracy definicja i dyskusja nad prorodzinnymi celami ulg podatkowych i innych świadczeń została pominięta. Autorka przyjmuje za Blundellem [Morawski, 2010], że - po pierwsze powinny one poprawiać redystrybucję dochodów, gwarantując pożądany standard życia osób o niskich dochodach. Po drugie, powinny zapobiegać odpływowi siły roboczej z rynku pracy, motywując ludzi do zapewniania sobie finansowej samowystarczalności. Po trzecie, powinny realizować wymienione cele w sposób kosztowo efektywny. 
dzietności) bez względu na ich status materialny czy dochodowy [Ministerstwo Finansów, 2010].

W pierwotnym brzmieniu przepisów określających podatek dochodowy od osób fizycznych wysokość ulgi prorodzinnej została uzależniona wyłącznie od liczby dzieci, nad którymi jest sprawowana opieka rodzicielska. Istotą ulgi od momentu jej wprowadzenia do konstrukcji podatku było obniżenie podatku obliczonego przez podatnika w rocznym zeznaniu podatkowym o kwotę odliczenia, przy czym podatek w pierwszej kolejności ulegał obniżeniu o obowiązkową składkę na ubezpieczenie zdrowotne. Ulga w ujęciu rocznym wynosiła 1112,04 zł na każde dziecko, w stosunku do którego była sprawowana opieka rodzicielska przez cały rok podatkowy $\mathrm{Z}$ punktu widzenia obowiązujących przepisów prawnych prawo do ulgi nie było obwarowane dodatkowymi kryteriami, np. wysokością dochodu podatnika czy statusem zatrudnienia, mimo że podobne kryteria obowiązują w systemie zasiłków rodzinnych. Ograniczenia co do prawa do ulgi wynikały natomiast z umieszczenia ulgi w konstrukcji właśnie podatku dochodowego od osób fizycznych. Skutkiem tego jest generalne ograniczenie grupy beneficjentów do podatników podatku dochodowego od osób fizycznych obliczających podatek według skali podatkowej. W rezultacie ze wsparcia są wykluczone te rodziny, których dochody pochodzą ze źródeł wyłączonych z obowiązku podatkowego na mocy ustawy (dotyczy to głównie przychodów z działalności rolniczej i leśnej). Z ulgi nie mogą skorzystać również podatnicy, którzy rozliczają podatek dochodowy od osób fizycznych według innych form, takich jak podatek liniowy, ryczałt od przychodów ewidencjonowanych oraz karta podatkowa.

W rezultacie z ulgi prorodzinnej w latach 2007-2013 skorzystało rocznie ok. $4 \mathrm{mln}$ podatników, stanowiących średnio tylko 17,35\% ogółu podatników podatku dochodowego od osób fizycznych (tab. 1). Wskaźnik ten uwzględnia wyłącznie podatników, na których ciąży obowiązek złożenia zeznania podatkowego. Ponadto w statystykach są uwzględniani wyłącznie ci podatnicy, którzy rzeczywiście dokonali odliczenia, pełnego lub częściowego. Natomiast brak jest jakichkolwiek danych na temat tych podatników, którzy posiadali prawo do ulgi, ale nie zrealizowali go w pełnej kwocie. W latach 2007-2012 liczba dzieci, w stosunku do których rodzice skorzystali z ulgi, pozostawała stabilna i wynosiła ok. $6,3 \mathrm{mln}$. Z danych gromadzonych przez GUS wynika, że odliczenie zrealizowano w przypadku ok. $71 \%$ dzieci $^{6}$ [GUS, 2014].

5 Prawo do ulgi na dziecko przysługuje na każde małoletnie dziecko w związku z wykonywaniem władzy rodzicielskiej oraz $\mathrm{w}$ związku ze sprawowaniem funkcji opiekuna prawnego lub rodziny zastępczej, a w przypadku pełnoletniego dziecka - w związku z wykonywaniem przez tych podatników ciążącego na nich obowiązku alimentacyjnego. Ulga na dzieci przysługuje, jeśli dziecko nie ukończyło 18. roku życia (bezwarunkowo) lub 25. roku życia, gdy kontynuowało naukę i nie uzyskało w danym roku podatkowym dochodów przekraczających kwotę wolną od podatku [szerzej: Ustawa..., 1991, art. 27f].

6 Według danych gromadzonych przez GUS w $2011 \mathrm{r}$. w polskich rodzinach na utrzymaniu pozostawało 8868,8 tys. dzieci do 24. roku życia. Brak jest natomiast informacji, w stosunku do ilu z nich nie przysługiwało prawo do ulgi prorodzinnej, np. ze względu na brak kontynuowania edukacji. 
Pobrane z czasopisma Annales H - Oeconomia http://oeconomia.annales.umcs.pl

Data: 26/04/2023 13:26:29

RENATA BUDLEWSKA

Tab. 1. Wykorzystanie ulgi prorodzinnej w latach 2007-2013

\begin{tabular}{|c|c|c|c|c|c|c|c|c|}
\hline \multicolumn{2}{|c|}{ Wyszczególnienie } & 2007 & 2008 & 2009 & 2010 & 2011 & 2012 & 2013 \\
\hline \multicolumn{2}{|c|}{ Liczba dzieci (w tys.) } & 6017 & 6358 & 6275 & 6287 & 6294 & 6167 & 5825 \\
\hline \multicolumn{2}{|c|}{ Liczba podatników (w tys.) } & 3974 & 4206 & 4337 & 4303 & 4364 & 4334 & 4024 \\
\hline $\mathrm{I}$ & \multirow{3}{*}{$\begin{array}{l}\text { przedział skali } \\
\text { podatkowej }\end{array}$} & 3552 & 3572 & 4207 & 4157 & 4187 & 4149 & 3913 \\
\hline II & & 355 & 517 & 130 & 146 & 176 & 185 & 111 \\
\hline III & & 67 & 117 & - & - & - & - & - \\
\hline \multicolumn{2}{|c|}{ Kwota odliczeń (w mld zf) } & 5,43 & 6,04 & 5,63 & 5,68 & 5,74 & 5,70 & 5,53 \\
\hline $\mathrm{I}$ & \multirow{3}{*}{$\begin{array}{c}\text { przedział skali } \\
\text { podatkowej }\end{array}$} & 4,72 & 4,95 & 5,42 & 5,44 & 5,45 & 5,39 & 5,29 \\
\hline II & & 0,59 & 0,89 & 0,21 & 0,24 & 0,29 & 0,30 & 0,24 \\
\hline III & & 0,12 & 0,21 & - & - & - & - & - \\
\hline \multicolumn{2}{|c|}{$\begin{array}{l}\text { Przeciętna kwota odliczona na } 1 \\
\text { dziecko (w zł) }\end{array}$} & 903 & 951 & 898 & 904 & 912 & 924 & 949 \\
\hline \multicolumn{2}{|c|}{$\begin{array}{l}\text { Przeciętna kwota odliczona na } 1 \\
\text { podatnika (w zf) }\end{array}$} & 1367 & 1437 & 1299 & 1321 & 1315 & 1315 & 1374 \\
\hline I & \multirow{3}{*}{$\begin{array}{c}\text { przedział skali } \\
\text { podatkowej }\end{array}$} & 1329 & 1385 & 1288 & 1310 & 1301 & 1300 & 1352 \\
\hline II & & 1673 & 1719 & 1635 & 1639 & 1669 & 1638 & 2151 \\
\hline III & & 1765 & 1786 & - & - & - & - & - \\
\hline
\end{tabular}

Źródło: [Ministerstwo Finansów, 2014].

Z ulgi prorodzinnej korzystali głównie ci podatnicy, którzy wykazali dochody poniżej I progu skali podatkowej, natomiast podatnicy rozliczający podatek według stawki podatku 32\% stanowili maksymalnie 4,28\% ogółu beneficjentów (w 2012 r.), przy czym już w 2013 r., na skutek wprowadzonych zmian, odsetek ten spadł o 1,5 p.p. Z informacji przedstawionych przez Ministerstwo Finansów wynika ponadto, że ponad połowa (tj. 56,4\%) podatników odliczających ulgę prorodzinną wykazała w zeznaniach podatkowych dochód roczny nieprzekraczający 30000 zł (tab. 2), co umożliwia realizację prawa do ulgi prorodzinnej jedynie w stosunku do jednego dziecka ${ }^{7}$.

W zeznaniach podatkowych za $2013 \mathrm{r}$. podatnicy mieli prawo do odliczania kwot ulgi prorodzinnej za trzecie, czwarte i kolejne dziecko, wyższych o odpowiednio 50 i 100\% w stosunku do kwot obowiązujących w latach poprzednich, tj. 139,01 zł miesięcznie za trzecie dziecko i 185,34 zł za czwarte i kolejne. Jednocześnie ograniczono prawo do ulgi w stosunku do podatników sprawujących opiekę nad jednym dzieckiem. Wprowadzenie zmian umotywowano koniecznością większego wsparcia materialnego rodzin z dziećmi. Czy rzeczywiście zmiany przyczyniły się do realizacji tego postulatu? Interesujące jest, że pomimo zmian wprowadzonych w konstrukcji ulgi przeciętne odliczenie podatników, których dochody nie przekroczyły I progu skali podatkowej, utrzymuje się na podobnym poziomie w pełnym okresie obowiązywania preferencji (1324 zł za lata 2007-2013). W grupie podatników, których dochody uplasowały się w II progu skali, przeciętne odliczenie jest wyższe o 30,86\% i wynosi 1732 zł. Najbardziej spektakularny wzrost odliczenia wystąpił właśnie w 2013 r. - podatnicy z II przedziału skali odliczyli wówczas przeciętnie 2151 zł na jedno dziecko. Ze względu na zmianę konstrukcji ulgi w 2013 r. największe korzy-

7 Co zostanie potwierdzone wynikami obliczeń przeprowadzonych w kolejnym rozdziale pracy. 
ści odnoszą więc podatnicy bardziej zamożni. Niewątpliwe jest zatem, że wsparcie rodzin wielodzietnych jako cel wprowadzonych zmian faktycznie mija się z celem wsparcia dla rodzin najuboższych.

Tab. 2. Struktura podatników dokonujących odliczenia ulgi prorodzinnej w 2009 r.

\begin{tabular}{|c|c|c|c|c|}
\hline \multirow{2}{*}{$\begin{array}{l}\text { Dochód } \\
\text { (w tys. zł) }\end{array}$} & \multicolumn{3}{|c|}{ Liczba podatników } & \multirow{2}{*}{$\begin{array}{l}\text { Liczba dzieci } \\
\text { (w tys.) }\end{array}$} \\
\hline & $\begin{array}{l}\text { Ogółem } \\
\text { (w tys.) }\end{array}$ & $\begin{array}{l}\text { Odliczających ulgę } \\
\text { na dzieci (w tys.) }\end{array}$ & $\begin{array}{c}\text { Odliczających ulgę } \\
\text { na dzieci }(\mathrm{w} \%)\end{array}$ & \\
\hline \multicolumn{5}{|c|}{ Rozliczenie indywidualne i w sposób przewidziany dla osób samotnie wychowujących dzieci } \\
\hline$<15$ & 4207 & 338 & $8,0 \%$ & 432 \\
\hline $15-30$ & 2403 & 470 & $19,6 \%$ & 617 \\
\hline $30-45$ & 1252 & 335 & $26,8 \%$ & 472 \\
\hline $45-60$ & 580 & 169 & $29,1 \%$ & 241 \\
\hline $60-75$ & 233 & 75 & $32,4 \%$ & 109 \\
\hline $75-90$ & 122 & 35 & $28,7 \%$ & 50 \\
\hline $90<$ & 183 & 61 & $33,3 \%$ & 86 \\
\hline \multicolumn{5}{|c|}{ Wspólne rozliczenie małżonków } \\
\hline$<15$ & 2853 & 597 & $20,9 \%$ & 866 \\
\hline $15-30$ & 3524 & 1039 & $29,5 \%$ & 1557 \\
\hline $30-45$ & 1858 & 629 & $33,8 \%$ & 946 \\
\hline $45-60$ & 846 & 297 & $35,1 \%$ & 450 \\
\hline $60-75$ & 367 & 130 & $35,4 \%$ & 196 \\
\hline $75-90$ & 196 & 72 & $36,7 \%$ & 107 \\
\hline $90<$ & 256 & 90 & $35,2 \%$ & 145 \\
\hline Razem & 18881 & 4337 & $23,0 \%$ & 6274 \\
\hline
\end{tabular}

Źródło: [Ministerstwo Finansów, 2014].

W latach 2007-2013 ulga prorodzinna przyjmowała formę ulgi bezzwrotnej, co w praktyce oznaczało, że opiekun prawny spełniający wszystkie warunki do objęcia ulgą w danym roku podatkowym mógł odliczyć jedynie tyle, na ile umożliwiał to płacony przez niego podatek, a właściwie determinujący wysokość tego podatku dochód. Przeciętna kwota odliczenia na jedno dziecko była najwyższa w $2008 \mathrm{r}$. (951 zł). Po spadku o 53\% w 2009 r. (najprawdopodobniej na skutek zmiany skali podatkowej) bardzo powoli wzrasta. Jednak nawet w $2013 \mathrm{r}$. nie osiągnęła poziomu z 2008 r. Wysokość średniego odliczenia niezmiennie wskazuje zatem na korzystanie $\mathrm{z}$ odliczeń $\mathrm{w}$ niepełnej kwocie, nawet na jedno dziecko. Wniosek ten potwierdza przeprowadzona przez Ministerstwo Finansów w 2009 r. analiza efektywności ulgi na dzieci. Niestety, brak jest w niej informacji o strukturze grupy podatników, którzy bądź nie wykorzystują ulgi w całości, bądź wykorzystują ją częściowo. Pewnych informacji na ten temat dostarczają m.in. symulacje przeprowadzone na potrzeby projektu Prezydenta RP pt. Dobry klimat dla rodziny, w świetle których ulgi prorodzinnej nie wykorzystuje w pełnej wysokości blisko $70 \%$ rodzin wychowujących troje i więcej dzieci, podczas gdy w rodzinach z jednym i dwojgiem dzieci wskaźnik ten nie przekracza 10\% [Myck, Kundera, Oczkowska, 2013]. 


\section{Konsekwencje zmiany formuly ulgi prorodzinnej w 2014 r.}

Celem zmian wprowadzonych w konstrukcji ulgi prorodzinnej w 2014 r. było dodatkowe wsparcie podatników o niskich dochodach, mających na utrzymaniu dzieci, oraz zwiększenie kwoty ulgi na dzieci dla podatników wychowujących troje i więcej dzieci. Ustawodawca w projekcie regulacji stwierdził, że

[...] systematyczna polityka wspierania rodzin (prowadzona do tej pory) spowodowała, że niemal połowa podatników (49\%) posiadających troje lub więcej dzieci nie płaci podatku dochodowego. Podatku nie płaci także co czwarty wychowujący dwoje dzieci (27\%). Mimo tych rozwiązań w dalszym ciągu część podatników nie ma jednak możliwości odliczenia ulgi w pełnej wysokości z uwagi na niski dochód i w konsekwencji niski podatek. Wsparcie z tytułu ulgi na dzieci nie jest w przypadku tych podatników realizowane w wystarczającym stopniu [Projekt..., 2014].

Aby zrealizować tak sformułowane cele, dokonano kolejnego podwyższenia kwot ulgi prorodzinnej, tj. o 20\% na trzecie i każde kolejne dziecko, co oznacza, że ulga na trzecie dziecko wynosi w skali roku 2000,04 zł, zaś na kolejne dzieci -2700 zł. Najbardziej istotna zmiana została przeprowadzona jednak w stosunku do samej konstrukcji ulgi podatkowej. Począwszy od zeznań podatkowych za 2014 r., nieodliczona ze względu na zbyt niski podatek część ulgi prorodzinnej jest podatnikowi zwracana, jednak w kwocie nie wyższej niż suma składek na ubezpieczenia społeczne i ubezpieczenie zdrowotne odliczona w składanym zeznaniu podatkowym. Według ustawodawcy wprowadzone zmiany zrównają sytuację podatników wychowujących dzieci, którzy uzyskują dochody w wysokości umożliwiającej skorzystanie z ulgi na dzieci, z sytuacją tych podatników, którzy wcześniej - z uwagi na zbyt niski dochód i w konsekwencji niski podatek - takiej możliwości nie mieli.

Weryfikacja realizacji założeń ulgi prorodzinnej funkcjonującej w nowym kształcie od 2014 r. zostanie przeprowadzona w oparciu o analizę porównawczą dochodu pozwalającego na odliczenie ulgi w pełnej wysokości we wszystkich latach obowiązywania ulgi, tj. 2007-2014. Aby ustalić wysokość dochodu pozwalającego na realizację prawa do odliczenia ulgi prorodzinnej w całości, przyjęto założenie, że podatnik osiąga dochód $\mathrm{w}$ formie wynagrodzenia przez cały rok podatkowy. Obliczony podatek jest wynikiem zastosowania skali podatkowej obowiązującej w poszczególnych latach, przychód został pomniejszony o koszty uzyskania przychodu właściwe przychodom ze stosunku pracy, zaś dochód i podatek zostały obniżone o składki na ubezpieczenia społeczne i składkę na ubezpieczenie zdrowotne ustalone według wymiaru obowiązującego w poszczególnych latach.

Wysokość wynagrodzenia pozwalająca na pełne odliczenie ulgi na jedno dziecko w latach 2007-2013 kształtuje się na zbliżonym poziomie, tj. 1796 zł (tab. 3). Oznacza to, że pełne korzyści z ulgi prorodzinnej przed wprowadzonymi zmianami 
Pobrane z czasopisma Annales H - Oeconomia http://oeconomia.annales.umcs.pl

Data: 26/04/2023 13:26:29

ULGA NA DZIECI JAKO INSTRUMENT REALIZACJI POLITYKI PRORODZINNEJ W POLSCE

Tab. 3. Symulacja wysokości miesięcznego wynagrodzenia brutto pozwalającego na pełne odliczenie ulgi prorodzinnej

\begin{tabular}{|c|c|c|c|c|c|c|c|c|}
\hline $\begin{array}{l}\text { Wysokość wynagrodzenia brutto/ } \\
\text { maksymalna kwota odliczenia (zł) }\end{array}$ & 2007 & 2008 & 2009 & 2010 & 2011 & 2012 & 2013 & 2014 \\
\hline \multirow{2}{*}{ Jedno dziecko } & 1760 & 1675 & 1796 & 1796 & 1796 & 1796 & 1796 & 456 \\
\hline & \multicolumn{8}{|c|}{93} \\
\hline \multirow{2}{*}{ Dwoje dzieci } & 2765 & 2623 & 2837 & 2837 & 2837 & 2837 & 2837 & 858 \\
\hline & \multicolumn{8}{|r|}{185} \\
\hline \multirow{2}{*}{ Troje dzieci } & 3782 & 3580 & 3888 & 3888 & 3888 & 3888 & 4409 & 1432 \\
\hline & \multicolumn{6}{|c|}{278} & 324 & 352 \\
\hline \multirow{2}{*}{ Czworo dzieci } & 4799 & 4538 & 4941 & 4941 & 4941 & 4941 & 6511 & 2202 \\
\hline & \multicolumn{6}{|c|}{371} & 510 & 577 \\
\hline
\end{tabular}

Źródło: opracowanie własne.

przysługiwały wyłącznie tym rodzicom, których wynagrodzenia przekraczały poziom minimalnego wynagrodzenia w gospodarce narodowej (rys. 1). Dochód ten powinien być proporcjonalnie wyższy, aby nabyć pełne prawo do odliczenia w przypadku wychowywania dwojga, trojga i czworga dzieci. W 2013 r., gdy zwiększając wysokość odliczenia przysługującego z tytułu wychowywania trzeciego i kolejnego dziecka, ustawodawca postulował poprawę sytuacji materialnej rodzin wielodzietnych, w rzeczywistości pomoc została skierowana do podatników, których wynagrodzenie za 1 miesiąc było równe co najmniej 4511 zł, zaś korzyść z tego tytułu wynosiła 324 zł. Jednocześnie rodzice, którzy nie osiągali takich dochodów, nie odliczali ulgi za trzecie i kolejne dziecko w pełnej wysokości.

Na skutek zmian wprowadzonych w 2014 r. poziom dochodów pozwalających na pełną realizację prawa do ulgi zdecydowanie spadł. Pełne odliczenie ulgi przysługującej na wychowywanie jednego dziecka jest możliwe już w przypadku mie-

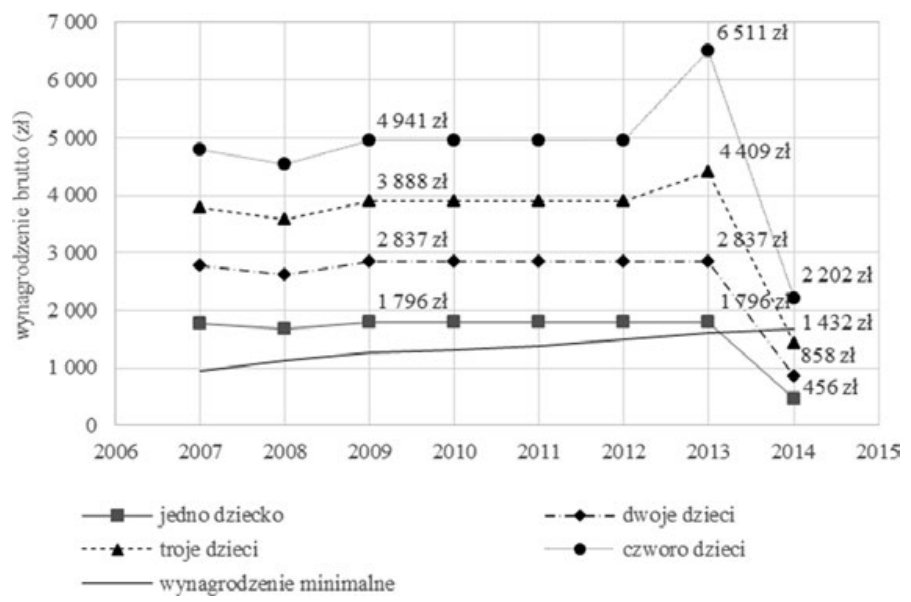

Rys. 1. Minimalna wysokość miesięcznego wynagrodzenia brutto pozwalającego na pełne odliczenie ulgi prorodzinnej

Źródło: opracowanie własne. 
sięcznego dochodu równego 456 zł (rys. 2). Rodzic wychowujący czworo dzieci może osiągnąć maksymalne korzyści z odliczenia, tj. 577 zł, jeśli jego miesięczne wynagrodzenie brutto wynosi minimum 2202 zł. Warto zwrócić uwagę, że te same korzyści z odliczenia będą konsumować również podatnicy, którzy osiągają wyższe wynagrodzenia. Nie obowiązuje bowiem tutaj ograniczenie dochodów właściwe uldze na jedno dziecko. Wobec tego, w wyniku wprowadzonych zmian w uldze prorodzinnej w 2014 r., ustawodawca faktycznie kieruje wyższe wsparcie do rodzin wielodzietnych, nie uzależniając go od sytuacji materialnej tych rodzin.
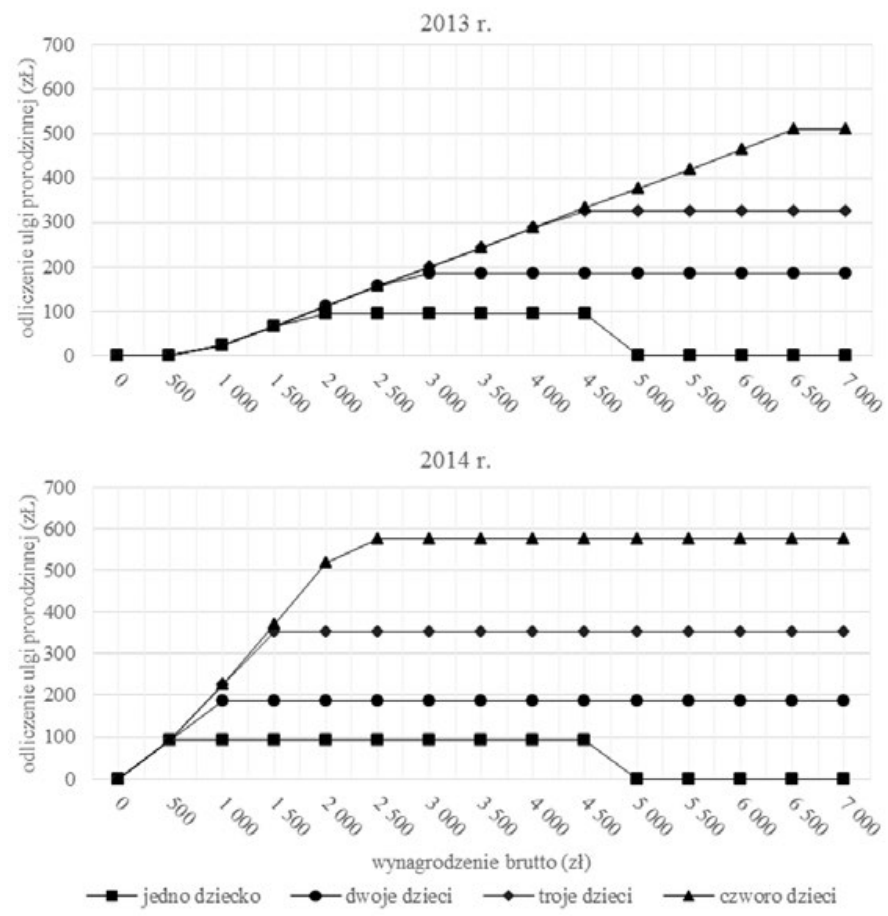

Rys. 2. Porównanie korzyści wynikających z zastosowania ulgi prorodzinnej w 2013 i 2014 r.

Źródło: opracowanie własne.

\section{Podsumowanie}

Na skutek zmian wprowadzonych w uldze prorodzinnej w 2014 r. znacznie zwiększyło się grono podatników, którzy mogą skorzystać z odliczenia. Ponadto podatnikom umożliwiono realizację pełnego odliczenia niezależnie od poziomu wypracowanego dochodu. W tym sensie należy pozytywnie ocenić wprowadzone zmiany. Natomiast należy zwrócić uwagę, że niestety wciąż pozostaje grono rodziców, którzy nie mogą skorzystać z ulgi wcale bądź w pełnym stopniu ze względu 
na to, że nie osiągają dochodu bądź osiągnięty dochód i opłacone składki na ubezpieczenia społeczne i ubezpieczenie zdrowotne są zbyt niskie. W konsekwencji ulga na dzieci pozostaje wciąż dodatkowym dochodem tylko dla tych podatników, którzy są aktywni zawodowo, zaś w przypadku rodzin wielodzietnych ta aktywność zawodowa powinna ponadto przekładać się na dochody co najmniej na poziomie przeciętnego wynagrodzenia. Można zatem zgodzić się ze stwierdzeniem, że ulga prorodzinna poprawia sytuację materialną tylko wybranych rodzin. Natomiast mimo wprowadzonych zmian wydaje się potwierdzać obawa, że „,preferencje trafiają nie tylko do potrzebujących, ale także do tych, dla których nie mają żadnego znaczenia, a są wręcz niezauważalne" [Podstawka, Deresz, 2008]. Należy zatem rozważyć definitywną zmianę konstrukcji ulgi prorodzinnej bądź zastąpienie jej świadczeniem bezpośrednim.

\section{Bibliografia}

GUS, Podstawowe informacje o rozwoju demograficznym Polski do 2014 roku, Warszawa 2015.

GUS, Rocznik statystyczny Rzeczypospolitej Polskiej 2014, Warszawa 2014.

Ministerstwo Finansów, Informacja dotycząca rozliczenia podatku dochodowego od osób fizycznych za 2013 rok, Warszawa 2014 (i wersje poprzednie).

Ministerstwo Finansów, Preferencje podatkowe w Polsce, Warszawa 2010.

Ministerstwo Finansów, Preferencje podatkowe w Polsce. Raport nr 5, Warszawa 2015.

Morawski L., Ulga podatkowa z tytułu wychowywania dzieci-efekty i propozycja zmian, „Polityka Społeczna" 2010, nr 1.

Myck M., Kundera M., Oczkowska M., Finansowe wsparcie rodzin z dziećmi w Polsce w 2013 roku. Raport Mikrosymulacyjny: 01/13, Fundacja Centrum Analiz Ekonomicznych CenEA, Szczecin 2013.

Podstawka M., Deresz A., Podatek dochodowy od osób fizycznych: progresywny czy proporcjonalny?, „Zeszyty Naukowe Szkoły Głównej Gospodarstwa Wiejskiego. Ekonomika i Organizacja Gospodarki Żywnościowej" 2008, nr 71.

Projekt ustawy o zmianie ustawy o podatku dochodowym od osób fizycznych oraz niektórych innych ustaw z dnia 29 września 2014 r., Sejm Rzeczypospolitej Polskiej, Druk nr 2871 z dnia 1 października 2014 r.

Rządowa Rada Ludnościowa, Sytuacja demograficzna Polski. Raport 2013-2014, Warszawa 2014.

Sobociński M., Polityka rodzinna w Polsce. W stronę zrównoważonego modelu, Instytut Spraw Publicznych, Warszawa 2014.

Ustawa z dnia 26 lipca 1991 r. o podatku dochodowym od osób fizycznych (Dz. U. z 1991 r., nr 80, poz. 350).

\section{Child Tax Credit as an Instrument of Family Policy in Poland}

In recent years, the support of family is one of the key areas of activity of Polish public authorities. In addition to the public spending realised in a traditional way, public funds are directed to families in Poland by means of tax credits included in the construction of particular taxes. The child tax credit was the greatest tax expenditure supporting families with children in the Polish tax system in 2013. The aim of the study is an indication of the consequences of family policy in Poland using the child tax credit. Consequently, the area was narrowed to the presentation of selected aspects allowing an assessment of the effectiveness of this tax relief. 
Pobrane z czasopisma Annales $\mathrm{H}$ - Oeconomia http://oeconomia.annales.umcs.pl Data: 26/04/2023 13:26:29

\section{Ulga na dzieci jako instrument realizacji polityki prorodzinnej w Polsce}

Wsparcie rodziny jest w ostatnich latach jednym z kluczowych obszarów aktywności polskich władz publicznych. Poza tradycyjnie realizowanymi wydatkami publicznymi, środki publiczne są kierowane do rodzin w Polsce za pomocą ulg podatkowych zawartych w konstrukcji poszczególnych podatków. W $2013 \mathrm{r}$. największą ulgą w polskim systemie podatkowym, bezpośrednio skierowaną do rodzin z dziećmi, była tzw. ulga prorodzinna. Celem opracowania jest wskazanie konsekwencji realizacji polityki prorodzinnej w Polsce za pomocą tej ulgi. Obszar konsekwencji został zawężony do prezentacji wybranych aspektów pozwalających na ocenę skuteczności ulgi, ze szczególnym uwzględnieniem oceny zmian wprowadzonych do konstrukcji ulgi w ubiegłych latach. 